\title{
Evaluation of Twenty Seven Sugar Beet Genotypes for Resistant to Root- Knot Nematode, (Meloidogyne Javanica)
}

\author{
Saleh, M.S. ${ }^{1}$; A.K. EL-Sayed ${ }^{2}$; I. M.A. Gohar ${ }^{3}$ and Nancy A. Abo Ollo ${ }^{2}$
}

\begin{abstract}
Sugar beet has been commercially introduced in Egypt since 1982 with cultivated area about 20,000 feddans and increased gradually to be 25,7667 fed. in 2008 . The plan is to increase the sugar beet area and beet sugar factories to fill the gap between sugar consumption and production which reaches about one million tons a broadly imported every year. Recently, reclaimed desert irrigated lands at West Nubariya and El-Bostan regions has shown that sugar beet can be successfully grown under sandy soil area condition and it's considered as the extended area for sugar beet production in Egypt. The root-knot nematode, (Meloidogyne incognita and M.-javanica), is the most serious problem against sugar beet expansion in the new arable lands which was reported as major nematode pests of sugar beet in Egypt. The present study was carried out during the growing season 2007 - 2008 at pots experiment in Sabahia Agricultural Research Station, Alexandria, Egypt, for evaluating the reaction of twenty seven sugar beet genotypes against the most serious nematode, (Meloidogyne javanica). The twenty seven sugar beet genotypes used in this test were 21 commercial varieties and 6 breeding materials.
\end{abstract}

Computed damage index classified the twenty seven sugar beet genotypes into four categories one commercial variety was highly susceptible (HS), nine genotypes were susceptible (S), thirteen genotypes moderate resistant (MR), and four genotypes resistant (R), three of them are commercial varieties while the best one in computed damage index was proven to be the breeding material (Eg.27).

\section{INTRODUCTION}

Sugar beet (Beta vulgaris), is an important arable crop, that traditionally used for sugar extraction, and recently, for biofuel production. A wide range of pests, including beet cyst nematode (Heterodera schachtii), root-knot nematodes (Meloidogyne spp.), green peach aphids (Myzus persicae) and beet root maggot (Tetanops myopaeformis), infest the roots or leaves of sugar beet, which leads to direct yield loss or through transmission of beet pathogens such as viruses. The average annual loss in yield of sugar beet due to $M$. incognita in different states in the U. S. A. was estimated to be as high as $10-50 \%$ and in Italy as 5-15
\% (Altman and Thomson, 1971). Conventional pest control approaches based on chemical application have led to high economic costs. Development of pestresistant sugar beet varieties could play an important role towards sustainable crop production while minimizing environmental impact. Yu, et al (1999) reported that development of commercially available plant resistant varieties to Meloidogyne spp. is essential for sugar beet caltivation. Intensive Beta germplasm screening has been fruitful, and genetic lines resistant to nematodes, aphids and root maggot have been identified and integrated into sugar beet breeding programmes. The use of transgenic technology is discussed with regard to biodiversity and food safety Zhang et al, (2008).

In Egypt, sugar beet is cultivated in 25,7667 feddans with an average production of about 18.593 tons per feddan 2007- 2008 (Annual Report of Sugar Crops Council, 2008). The most serious problem against sugar beet extension in new areas is root-knot nematode. Meloidogyne incognita and M. javanica were reported as major nematode pests of sugar beet in Egypt, (Ibrahim, 1982; Oteifa and El-Gindi, 1982; Abd El-Massih, 1985; Maareg et al. 1988, (a \& b), Maareg et al. 1998 and Ismail et al. 1996). Also, in Egypt, Koura (1983) carried out a survey work in sugar beet producing areas and recorded the presence of seven nematode genera, viz. Helicotylenchus, Hirschmanniella, Tylenchorhynchus, Hoplolaimus, Criconemoides and Pratylenchus in decreasing order. Maareg et al. (1988b) reported that the root-knot nematodes, Meloidogyne javanica and $M$. incognita are known among the most serious pests of sugar beet crop in Egypt.

Present investigation was carried out to study the reaction of twenty seven sugar beet genotypes (21 commercial varieties and 6 breeding materials) to the root-knot nematode ( $M$. javanica), to select resistant ones for planting in nematode contaminated areas and as a prospect to use in the evaluation purposes needed for breeding programs.

\footnotetext{
${ }^{1}$ Sugar Crops Research Institute, Department of Genetics and breeding.

${ }^{2}$ Department of Genetics, Faculty of Agriculture, University of

Alexandria- (Saba-Bacha),

${ }^{3}$ Sugar Crops Research Institute, Department of. Sugar Crops Pests

\&diseases Research

Received March 1, 2009, Accepted June30, 2009
} 


\section{MATERIAL AND METHODS}

\section{Materials:}

\subsection{Sugar beet genotypes:}

The twenty seven sugar beet genotypes used in this study consisted of twenty one commercial varieties and six breeding materials, sixteen polygerm and eleven monogerm. The tested genotypes were obtained from Sugar Crops Research Institute, Agriculture Research Center, Egypt. Table (1) presents the twenty seven sugar beet genotypes and its description.

\subsection{The root-knot nematode:}

The root-knot nematode, Meloidogyne javanica was originating from a sugar beet field in Nubariya district and its generic identification was based on the morphology of adult and larval form as described by Mai and Lyon (1975). Species of the root-knot nematode were identified on the basis of perineal pattern morphology of the adult females as described by Eisenback et al. (1980) and Eisenback (1985). Second stage juveniles (J2) of the root-knot nematodes, $M$. javanica were obtained from a pure culture of $M$. javanica that was previously initiated by a single eggmass and propagated on tomato plants, (Lycopersicon esculentum Mill. cv. Moneymaker) in the greenhouse

\section{METHODS:}

\subsection{Inoculum preparation:}

The root knot nematode, Meloidogyne javanica was cultured alternately on tomato or eggplant (Solanum melongena cv. Blackbeauty) and then sugar beet (Beta vulgaris cv. Chems). Eggs were extracted from tomato or eggplant roots by agitating in $0.05 \% \mathrm{NaOCl}$ for 2 to 3 min (Hussey and Barker, 1973). The eggs were then collected and rinsed with tap water on nested 150- and $25-\mu \mathrm{m}$ pore sieves. To collect the second-stage juveniles (J2) for use as inoculum infected tomato or eggplant roots were placed in hatching dishes and incubated in a mist chamber. The $\mathrm{J} 2$ were then collected using 150- and 25- $\mu \mathrm{m}$-pore sieves once a day for 3 to 5 d. During the collection period, J2 were stored in a 1$\mathrm{cm}$ aqueous suspension at $5^{\circ} \mathrm{C}$ prior to inoculation of sugar beet plants.

Table 1. Description of the twenty seven sugar beet genotypes evaluated for their resistance to the root-knot nematode, Meloidogyne javanica and its seed types

\begin{tabular}{|c|c|c|c|}
\hline Code & Sugar beet varieties & Genotypes handling category & Seed type \\
\hline A1 & Glorius & Commercial var. & polygerm \\
\hline $\mathrm{A} 2$ & Helwes & Commercial var. & polygerm \\
\hline A3 & Ds 9004 & Commercial var. & polygerm \\
\hline A4 & Francesca & Commercial var. & monogerm \\
\hline A5 & Rossanna & Commercial var. & monogerm \\
\hline A6 & 02-99 & Commercial var. & monogerm \\
\hline A7 & Lp-10 & Commercial var. & monogerm \\
\hline A8 & Lp-13 & Commercial var. & monogerm \\
\hline A9 & Rhist & Commercial var. & monogerm \\
\hline A10 & $05-99$ & Commercial var. & monogerm \\
\hline A11 & $01-99$ & Commercial var. & monogerm \\
\hline A12 & Toro & Commercial var. & polygerm \\
\hline A13 & FD-9902 & Commercial var. & polygerm \\
\hline A14 & Despreze & Commercial var. & polygerm \\
\hline A15 & Baraca & Commercial var. & polygerm \\
\hline A16 & Sultan & Commercial var. & polygerm \\
\hline A17 & Amile & Commercial var. & monogerm \\
\hline A18 & Eg. 2701 & Breeding material & polygerm \\
\hline A19 & SP. 270 & Breeding material & polygerm \\
\hline A20 & C. 39 & Breeding material & polygerm \\
\hline A21 & Athos poly & Commercial var. & polygerm \\
\hline A22 & Eg. 27 & Breeding material & polygerm \\
\hline A23 & Monte Bianco & Commercial var. & monogerm \\
\hline A24 & Eg. 26 & Breeding material & polygerm \\
\hline A25 & Type & Commercial var. & polygerm \\
\hline A26 & Eg. 6 & Breeding material & polygerm \\
\hline
\end{tabular}




\subsection{Inoculation procedure:}

Beet seeds of each tested genotype were sown in 25 $\mathrm{cm}$ diameter pots, filled with steam sterilized sandy clay soil $(2: 1, \mathrm{v} / \mathrm{v})$ and three replicates were used for each genotype. Seedlings were thinned to two per pot at the four to six leaves stage. Each plant was inoculated with about 2000 second-stage juveniles (J2) or/and (eggs + $\mathrm{J} 2 \mathrm{~s}$ ) suspension. Two holes about $5-\mathrm{cm}$ deep and 1-cm wide were made in the soil around each four week old sugar beet seedling in $2.5 \mathrm{ml}$ aliquot of inoculum suspension was applied to each hole with a pipette. Unless otherwise noted, the plants were maintained in a greenhouse at $25 \pm 2.5^{\circ} \mathrm{C}$. All pots were layout in a complete randomized block design in the greenhouse. Nutrients were supplied as liquid feed one each week with $5 \mathrm{ml}$ per pot of diluted Vitafeed III ${ }^{\circledR}\left(\mathrm{N}\right.$ : $\mathrm{P}_{2} \mathrm{O}_{5}$ : $\left.\mathrm{K}_{2} \mathrm{O}, 19: 19: 19 \%\right)$ and irrigated daily as required. Pots were maintained for 45 days after inoculation.

\subsection{Resistance assessment:}

After 45 days from inoculation, plants were uprooted carefully from pots. Infected roots of each plant were washed with tap water, fixed in $4 \%$ formalin for $24 \mathrm{~h}$ and stained in 0.01 lactic acid fuchsin (Byrd and Barker, 1983) and then examined for recording number of galls and eggmasses per root system.

The roots were, then graded for gall and egg-mass numbers, gall size (GS), gall index (G.I) and egg-mass index (E.I)., where a 1-9 scale for each of galls and eggmasses numbers was as follows:

-Gall index (G.I): $1=$ no galls, $2=1-5,3=6-10,4=$ $11-20,5=21-30,6=31-50,7=51-70,8=71-100$ and $9>100$ galls or egg-masses per plant.

-Gall size (G.S): was rated as $1=$ no galls, $3=$ very small, $5=$ small, $7=$ medium, and $9=$ big galls.

-Galled area (G.A.): $=1=<10 \%, 2=10-20 \%, 3=$ $21-30 \%, 4=31-40 \%, 5=41-50,6=51-60 \%, 7=61$ $-70 \%, 8=71-80 \%$ and $9=>80 \%$ of surface root area.

The damage index (D.I) was deduced by dividing the sum of G.I, G.S and G.A by 3 (D.I = G.I+G.S+G.A / 3). The different ratings of D.I were moderately resistant $(<5)$, susceptible $(5.1-7)$ and highly susceptible $(7.1$ - 9). Nematode damage index (D.I.) was evaluated according to (Sharma et al., 1994).

\subsection{Statistical analysis:}

The experimental design was randomized completed block design (RCBD) with three replicates, and the data was analyzed according to (Steel and Torrie, 1981).

\section{RESULTS AND DISCUSSION}

\section{The pots experimental results:}

After 45 days from artificial nematode inculcation the plants were carefully uprooted from the soil and the observations were recorded. Figure (1) shows uprooted seedlings after 45 days from pots. Figure (2) illustrates examined seedling for the twenty seven studied genotypes. There were significant differences in all three studied parameters.

\subsection{Gall index (GI):}

There were highly significant differences between genotypes in this gall index (GI). Table (2) presents mean values for gall index, these values ranged from 7 in commercial polygerm varieties (Helwes and FD9902), to 2.3 in breeding material Eg.27.

\subsection{Gall size (GS):}

Significant differences were found between genotypes for galls size. Figure, (3) illustrates different size of galls in seedling roots. Mean values in Table (2) indicates that these values ranged from 7 to 1.6. Highest values were found in ten genotypes, nine of them are commercial ones (Glorius, Ds 9004, Rossanna, 02-99, Rhist, Toro, FD-9902, Type and Armure), while one of them breeding material (Eg.6). Lowest values in this character found in three genotypes, two of them are commercial varieties (Sultan and Amile), while one breeding material (Eg.27).

\subsection{Galled area (GA):}

The data indicated that there were highly significant differences between genotypes in the values of root galled area. Table (2) shows mean values for gall area character, these values ranged from 7.6 in polygerm commercial variety (FD-9902) to 1.3 in monogerm commercial variety (Monte Bianco).

\section{Genotypes reaction against nematode:}

Categorization of the tested genotypes according to the damage index (DI) of (Sharma et. al., 1994) is shown in Table (3). Computed damage index classified the twenty seven sugar beet genotypes into four categories highly susceptible (HS), susceptible (S), moderate resistant (MR) and resistant (R).

\section{1- Highly susceptible genotypes (HS):}

Data indicated that there was one commercial variety as highly susceptible (HS), sugar beet polygerm commercial variety (FD-9902).

\section{2- Susceptible genotypes $(\mathrm{S})$ :}


There were nine genotypes considered as susceptible (S), four of them are monogerm (Rhist, 0299, Armure and Rosanna), four polygerm ( DS 9004,

Table 2. Investigated sugar beet genotypes and their reactions after nematode inoculation

\begin{tabular}{|c|c|c|c|c|}
\hline Sugar beet genotypes & Code & Gall index (GI) & Gall size index (GS) & Galled area index (GA) \\
\hline Glorius & A1 & 4 cde & $7 \mathrm{a}$ & $6.8 \mathrm{a}$ \\
\hline Helwes & A2 & $7 \mathrm{a}$ & $4 a b$ & $3.7 \mathrm{bc}$ \\
\hline Ds 9004 & A3 & $5 \mathrm{abcd}$ & $7 \mathrm{a}$ & $6.6 \mathrm{a}$ \\
\hline Francesca & A4 & $3.3 \mathrm{de}$ & $4.6 a b$ & $3.4 \mathrm{c}$ \\
\hline Rossanna & A5 & $4.6 \mathrm{bcd}$ & $7 \mathrm{a}$ & $6.9 \mathrm{a}$ \\
\hline $02-99$ & A6 & $5.3 \mathrm{abcd}$ & $7 \mathrm{a}$ & $7.2 \mathrm{a}$ \\
\hline Lp-10 & A7 & 4.3 bcde & $4 \mathrm{ab}$ & $3.7 \mathrm{bc}$ \\
\hline $\mathrm{Lp}-13$ & A8 & $3.3 \mathrm{de}$ & $4 \mathrm{ab}$ & $3.9 \mathrm{bc}$ \\
\hline Rhist & A9 & $5.6 \mathrm{abc}$ & $7 \mathrm{a}$ & $7.5 \mathrm{a}$ \\
\hline $05-99$ & A10 & $5.6 \mathrm{abc}$ & $4 \mathrm{ab}$ & $4.2 \mathrm{bc}$ \\
\hline $01-99$ & A11 & $5.3 \mathrm{abcd}$ & $4 a b$ & $3.7 \mathrm{bc}$ \\
\hline Toro & A12 & $5.6 \mathrm{abc}$ & $7 \mathrm{a}$ & $6.9 \mathrm{a}$ \\
\hline FD-9902 & A13 & $7 \mathrm{a}$ & $7 \mathrm{a}$ & $7.6 \mathrm{a}$ \\
\hline Despreze & A 14 & 3.6 cde & $4 \mathrm{ab}$ & $4.7 \mathrm{~b}$ \\
\hline Baraca & A 15 & $4.6 \mathrm{bcd}$ & $4 \mathrm{ab}$ & $3.9 \mathrm{bc}$ \\
\hline Sultan & A 16 & 4.3 bcde & $1.6 \mathrm{~b}$ & $1.5 \mathrm{~d}$ \\
\hline Amile & A 17 & 3.6 cde & $1.6 \mathrm{~b}$ & $1.4 \mathrm{~d}$ \\
\hline Eg. 2701 & A18 & $4.6 \mathrm{bcd}$ & $4 \mathrm{ab}$ & $3.3 \mathrm{c}$ \\
\hline SP. 270 & A19 & 4 cde & $4 a b$ & $3.4 \mathrm{c}$ \\
\hline C. 39 & A20 & $6.3 \mathrm{ab}$ & $4 a b$ & $4.3 \mathrm{bc}$ \\
\hline Athos poly & A21 & $3.6 \mathrm{cde}$ & $4 a b$ & $3.8 \mathrm{bc}$ \\
\hline Eg. 27 & A22 & $2.3 \mathrm{e}$ & $1.6 \mathrm{~b}$ & $1.5 \mathrm{~d}$ \\
\hline Monte Bianco & A23 & $3.3 \mathrm{de}$ & $1.67 \mathrm{~b}$ & $1.3 \mathrm{~d}$ \\
\hline Eg. 26 & A24 & $4.6 \mathrm{bcd}$ & $4 \mathrm{ab}$ & $3.9 \mathrm{bc}$ \\
\hline Type & A 25 & 4 cde & $7 \mathrm{a}$ & $6.7 \mathrm{a}$ \\
\hline Eg. 6 & A26 & $4.6 \mathrm{bcd}$ & $7 \mathrm{a}$ & $6.9 \mathrm{a}$ \\
\hline Armure & A27 & $5.3 \mathrm{abcd}$ & $7 \mathrm{a}$ & $7.1 \mathrm{a}$ \\
\hline L.S.D. 0.01 & & 1.76 & 2.63 & 0.997 \\
\hline
\end{tabular}

Table 3. Sugar beet varieties and their reaction after nematode inoculation (HS) highly sensitive, (S) sensitive, (MR) moderate resistant and (R) resistant

\begin{tabular}{cccc}
\hline Varieties reaction & Sugar beet varieties & Code & Computed damage index (DI) \\
\hline HS & FD 9902 & A13 & 7.2 \\
\hline & Rhist & A9 & 6.7 \\
S & $02-99$ & A6 & 6.5 \\
& Toro & A12 & 6.5 \\
& Armure & A3 & 6.4 \\
& DS 9004 & A5 & 6.2 \\
& Rosanna & A26 & 6.1 \\
& Eg.6 & A25 & 6.1 \\
& Type & A1 & 5.9 \\
Glorius & A2 & 5.9 \\
\hline Helwes & A20 & 4.9 \\
& C.39 & A10 & 4.8 \\
& A5-99 & A15 & 4.6 \\
& A1-99 & A24 & 4.4 \\
& Baraca & A4 & 4.1 \\
& Eg.26 & A7 & 4.1 \\
& Francesca & A18 & 4 \\
& LP-10 & A21 & 3.9 \\
& Eg-2701 & A14 & 3.8 \\
& SP-270 & A1 & 3.8 \\
& Asthos poly & A17 & 3.7 \\
& Despreze & LP-13 & 3.7
\end{tabular}




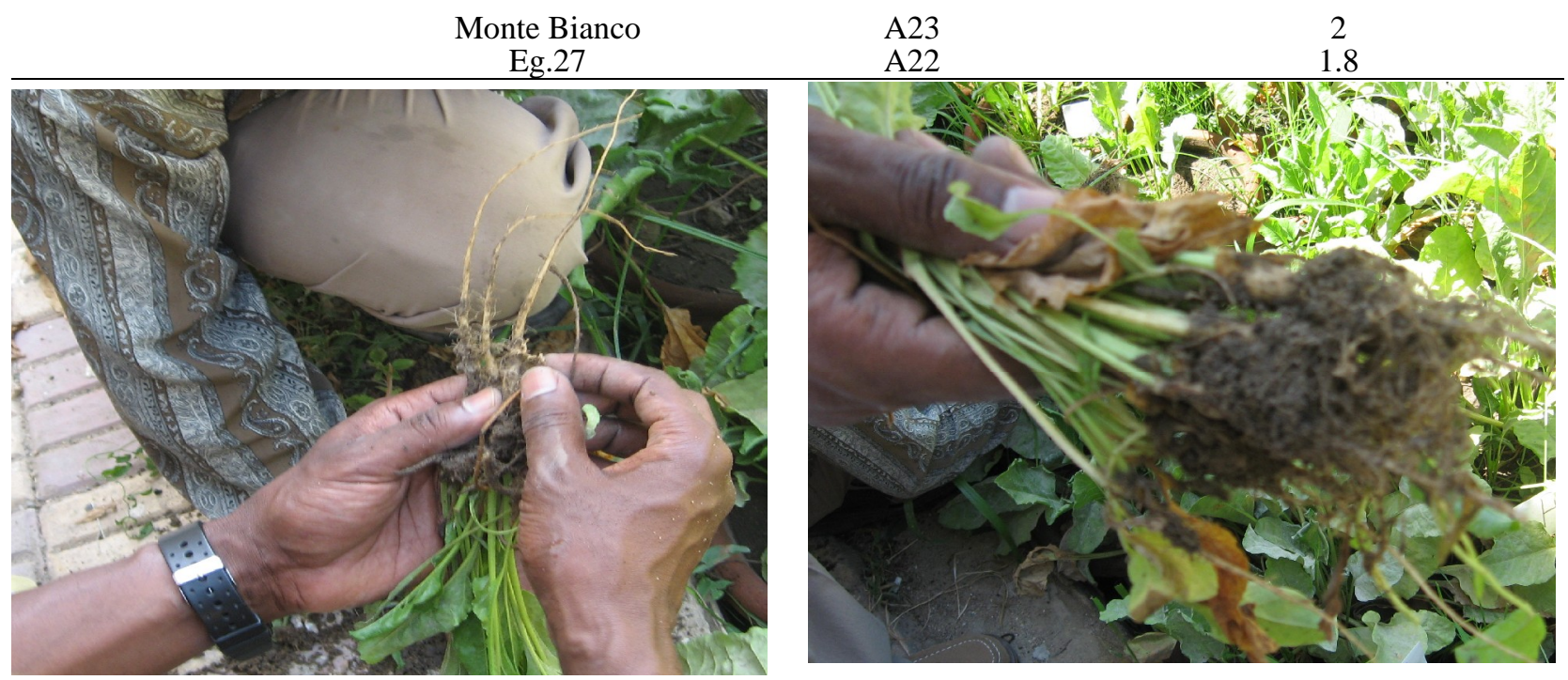

Figure 1. Uprooted sugar beet seedlings after 45 days of inoculation
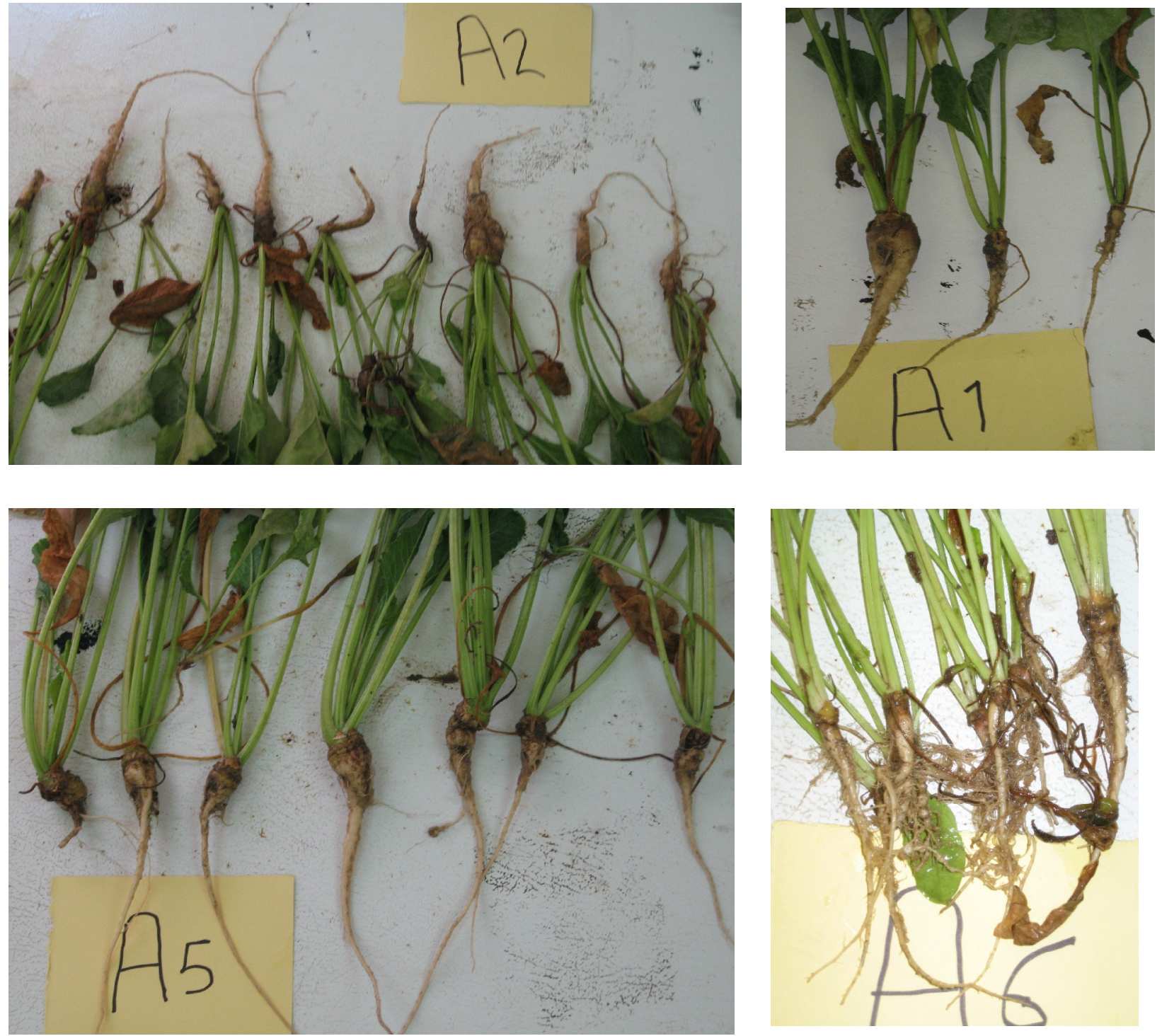
Figure 2. Sugar beet inoculated seedlings after 45 days of nematode inoculations
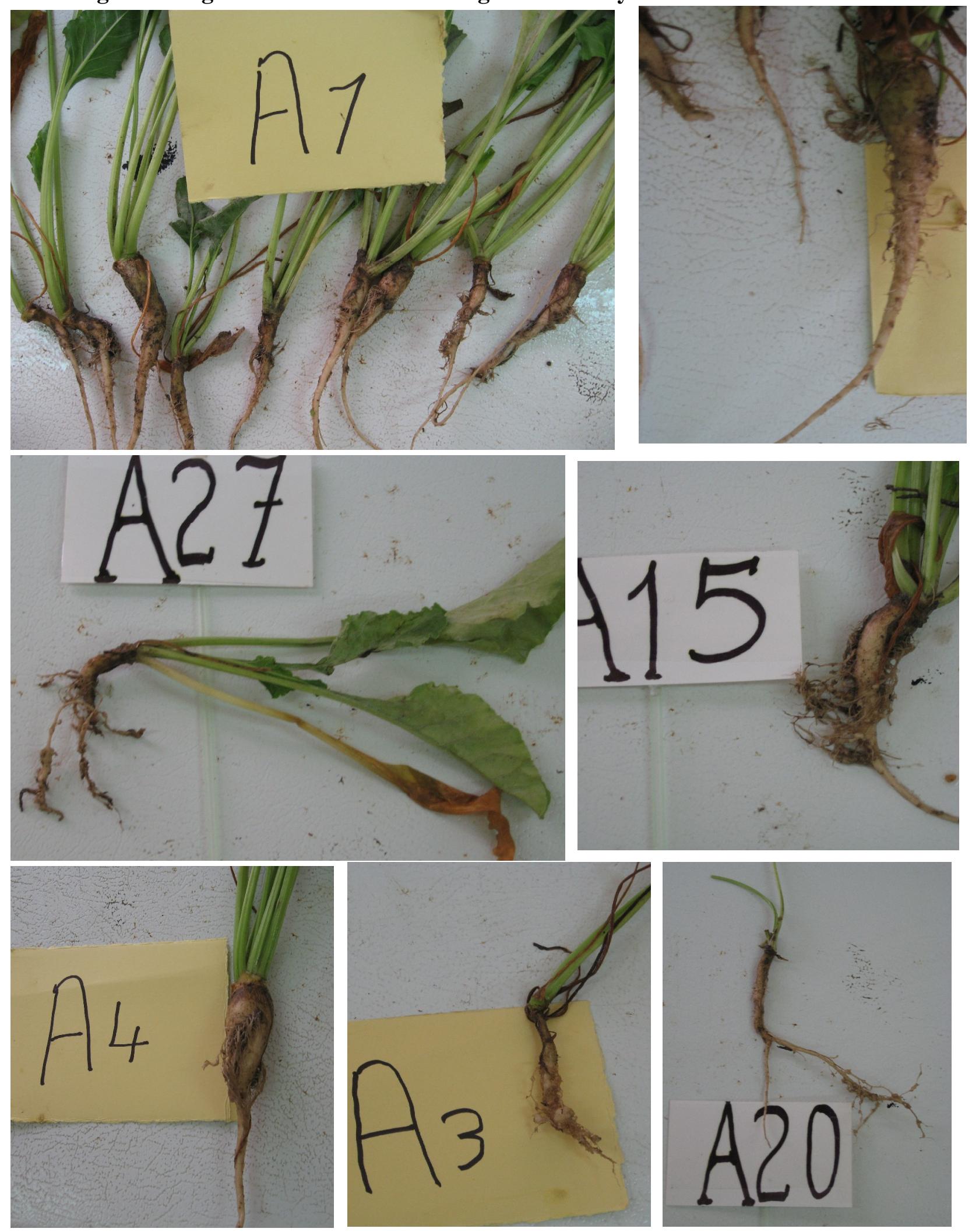


\section{Figure 3. Infected roots after 45 days of nematode inoculation. Photographs show different size of galls}

Glorius, Toro and Type) and one breeding material (Eg.6).

\section{3- Moderate resistant genotypes (MR):}

The obtained data indicate that there were thirteen genotypes considered as moderate resistant (MR), five of them are monogerm commercial variety $(01-99,05-$ 99, Lp-10, Lp-13 and Francesca), and four polygerm commercial varieties (Helwes, Baraca, Athos poly and Despreze), while there were four breeding materials (Eg.26, Eg.2701, Sp-270 and C.39).

\section{4- Resistant genotypes ( $R)$ :}

There were four genotypes in this category two of them were monogerm commercial varieties (Amile and Monte Bianco) and one polygerm commercial variety (Sultan), while the best of them was the breeding material (Eg.27). These results are in agreement with those reported by Gohar (2003) who used 21 sugar beet commercial varieties to study their susceptibility to root-knot nematode, Meloidogyne incognita, and the relationships between plant parasitic nematodes of sugar beet and other soil fauna. He found four commercial varieties were resistant to Meloidogyne incognita, two of them were polygerm (Kawemira and Sultan) and two were monogerm (Marathon and Emma). Muller (1992), reported that nematode resistant material is now incorporated into commercial breeding lines, so the appearance of nematode resistance cultivars is at last in prospect, although reports from Germany on resistance breaking pathotypes indicate that there are continuing problems in store for the plant breeder if resistant varieties become widely used. Ismail et al. (1996) screened twenty-six varieties of sugar beet for their susceptibility to Meloidogyne incognita under greenhouse conditions. They found that Carat variety could be ranked as a tolerant host and HM Hill2 and Maribo marine poly as a highly susceptible. Ten varieties out of 26 were rated as moderately susceptible, whereas the remaining varieties were as low as susceptible.

\section{REFERENCES}

Abd El-Massih, M.I. (1985). Biological studies on major plant parasitic nematodes infecting sugar beet in Egypt. Ph. D. Thesis, Fac. of Agric., Cairo Univ., 90 pp.

Altman, J. and Thomson, I. (1971). Nematodes and their control. In : Advances in sugarbeet production principles and practices. pp. 335-370 (ed. T.J. Russell, T.A. John, E.R. George and R.H. George).: The Iowa State Univ. Press. Ames, Iowa, U.S.A
Annual Report of Sugar Crops Council (2008). Sugar Crops Council Ministry of Agriculture and Land Reclamation, Giza, Egypt.

Byrd DW and K. K. Barker (1983). An improved technique for clearing and staining plant tissues for detection nematodes. J. Nematol., 15 (3): 142-143.

Eisenback, J.D. (1985). Detailed morphology and anatomy of second- stage juveniles, males and females of the genus Meloidogyne (root-knot nematodes). In: An advanced treatise on Meloidogyne. Eds., Sasser, J.N. and Carter, C.C., Biology and Control, North Carolina State University Graphics. pp 47-77.

Eisenback, J.D.; Hirschmann, H. and Triantaphyllou, A.C. (1980). Morphological comparison of Meloidogyne females head structures, perineal patterns and style. Journal of Nematology 12: 300-313.

Gohar, I.M.A. (2003). The relationships between plant parasitic nematodes of sugarbeet and other soil fauna. Ph.D. Thesis, Fac. Of Agric Moshtohor, Zagazig University, Egypt.

Hussey RS and KR Barker. 1973. A comparison of methods of collecting inocula of Meloidogyne spp. including a new technique. Plant Dis. Reptr. 57:1025-1028.

Ibrahim, I.K.A. (1982). Species and races of root-knot nematodes and their relationships to economic host plants in Northern Egypt. In: Proceedings of the Third Research and Planning Conference on Root-knot Nematode.

Ismail, A.E.; Aboul Eid, H.Z. and Besheit, S.Y. (1996). Effects of Meloidogyne incognita on growth response and technological characters of certain sugarbeet varieties. Afro-Asian Journal of Nematology, 6(2): 195202.

Koura, F.H. (1983). Distribution pattern of nematode genera associated with sugarbeet in Egypt. Bull. Zool. Soc. Egypt, 23: 67-70.

Maareg, M.F.; El-Deeb, M.H. and Ebieda, A.M. (1988 a). Susceptibility of ten sugarbeet cultivars to root-knot nematode, Meloidogyne spp. .Alexandria Science Exchange, 9(3): 293-302.

Maareg, M.F.; Hassanein, M.A. and Ebieda, A.M. (1988 b). Diseases of sugarbeet (Beta vulgaris L.) in Egypt. Aom. \& Dev. Res., 22: 65-73.

Maareg, M.F.; Hassanein, M.A.; Allam, A.I. and Oteifa, B.A. (1998). Susceptibilty of twenty-six sugarbeet varieties to root-knot nematodes, Meloidogyne spp. in the newly reclaimed sandy soils of Al-Bostan region. Egyptian Journal of Agronematology, 2(1): 11-125.

Mai, W.F. and Lyon, H.H. (1975). Pictorial key to genera of plant parasitic nematodes. $4^{\text {th }}$ Ed., Cornell Univ. Press, Ithaca, N.Y. 172 p. 
Muller, J. (1992). Detection of pathotypes by assessing the virulence of Heterodera schachtii populations. Nematologica, 38: 50 -64.

Oteifa, B.A. and El-Gindi, D.M. (1982). Relative susceptibility of certain commercially important cultivars to existing biotypes of Meloidogyne incognita and $M$. javanica in Nile-Delta, Egypt. In: Proceedings of the $3^{\text {rd }}$ Research and Planning. Conf. of Root-knot Nematodes, Meloidogyne spp. 13-17 September, 1982. Coimbra, Portugal. pp 66-84.
Sharma, S.B.; Mohiuddin, M.; Jain, K.C. and Remanandan, P. (1994). Reaction of pigeon pea cultivars and germplasm accessions to the root-knot nematode, Meloidogyne javanica. Journal of Nematology, 26: 644-652.

Steel, R.G.D. and J.H. Torrie (1981). Principles of statistics a biometrical approach. $2^{\text {nd }}$ ed. By McGraw-Hills International Book Company. Singapore, 633 p.

Yu, M. H.; W. Heijbroek and L. M. Pakish (1999). The sea beet source of resistance to multiple species of root-knot nematode. Euphytica. 108 (3): 151-155.

Zhang, C. L. Xu, D. C. Jiang, X. C. Zhou, Y. Cui, J. Zhang, C. X. Chen, D. F. Fowler, M. R. Elliott, M. C. Scott, N. W. Dewar and A. M. Slater (2008). A. Genetic approaches to sustainable pest management in sugar beet (Beta vulgaris). Annals of Applied Biology. 152 (2): 143-156. 


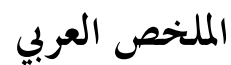

\section{تقييم سبعة وعشرون تركيب وراثى من بنجر السكر من حيث مقاومتها لنيماتودا تعقد الجذور (ميلودوجين جفنيكا )}

\author{
بحدى سعد صالح، أحمد السيد محمد خالد، إبراهيم محمد عبده جوهر، نانسى عبد السلام أبوعلو \\ أجرى هذا البحث بغرض تقييم YV من الطرز الوراثية لبنجر وقد أظهرت النتائج مايلى:
}

تم تقسيم السبعة وعشرون طراز وراثى تحت الدراسة إلى ع بحاميع

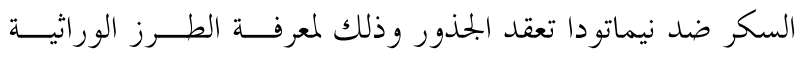
من حيث المقاومة إلى:

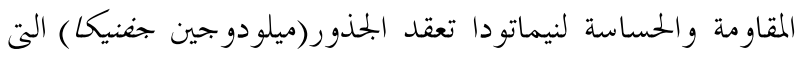
1- البحموعة الأولى (شديدة الحساسية) وقد أحتوت هذه المجموعة الأولى على صنف واحد بتحارى هو

$$
\text { الصنف عديد الأجنة (FD - (F902). }
$$$$
\text { ب- البحموعة الثانية (الحساسة) }
$$

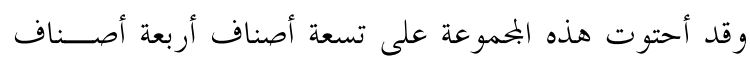

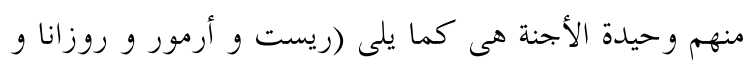
99

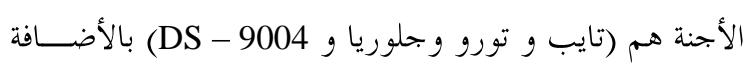

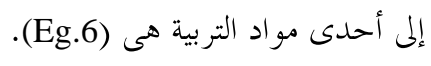
ب- البحموعة الثالثة (متوسط المقاومة) وأحتوت هذه البمموعة على النصيب الأكبر من السبع وعشرون

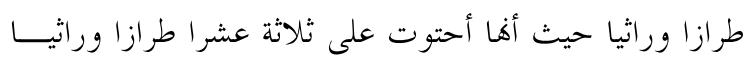

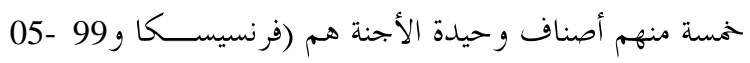

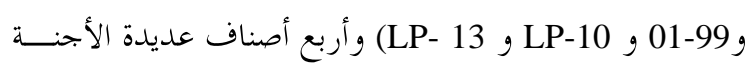
هم (هلويس وبر كة وأثوس بولى وديسبريز) بالأضافة إلى أربعة

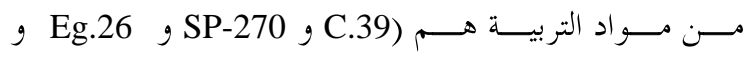

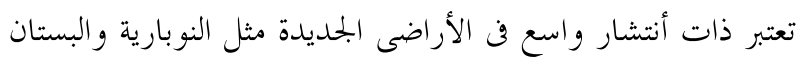

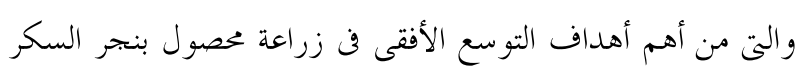

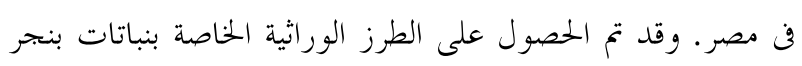

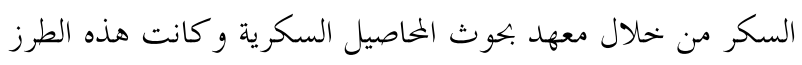

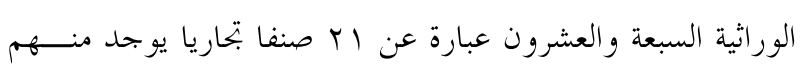

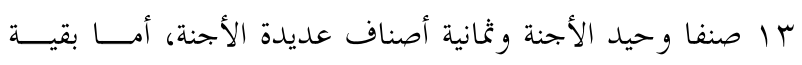

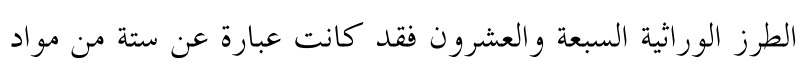

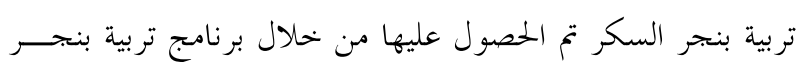
السكر المقام فن مصر منذ أكثر من عشرون عاما من خحلال العاملين

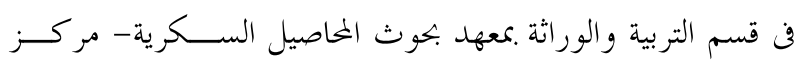
البحوث الز اعية- مصر.

وقد أجرى هذا البحث في معطة بحوث الصبحية بالإسكندرية

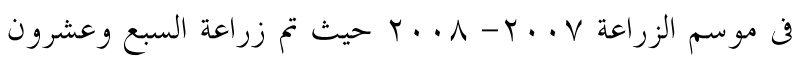

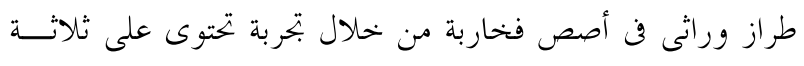

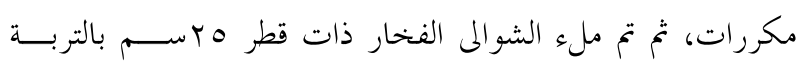

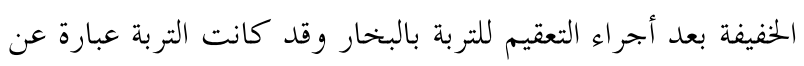
(r جزء رمل إلى اجزء طمى).

.(Eg.2701

$$
\text { ع - البحموعة الرابعة (المقاومة) }
$$

أحتوت هذه المجموعة على أربعة طرز وراثية أثنان منهم عبارة

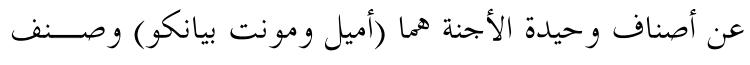

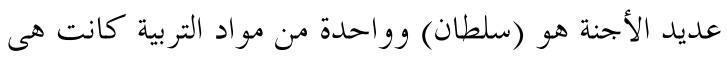

تم إجراء العدوى الصناعية بنيماتودا تعقد الجذور (ميلودوجين

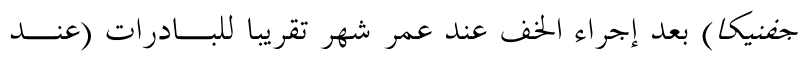

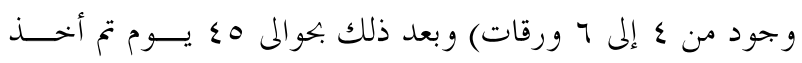

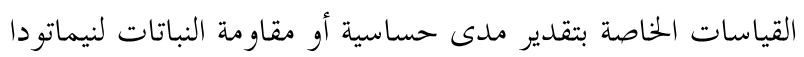
تعقد الجذور. 
الجيدة بالأضافة إلى درجة المقاومة المناسبة التى تجعلها تتميـزز

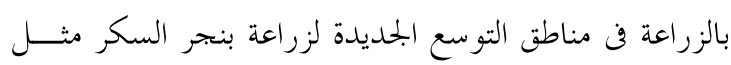

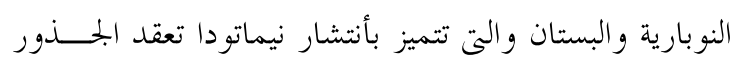

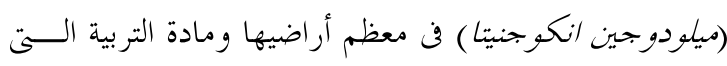

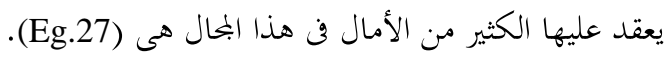

أكثرهم من حيث صفة المقاومة مما يعطى أنطباع جيد إلى أنه

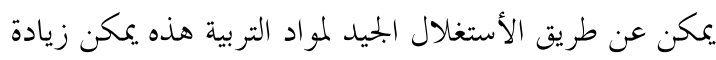

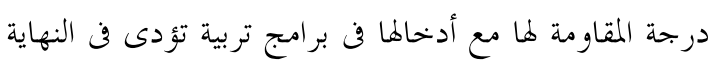

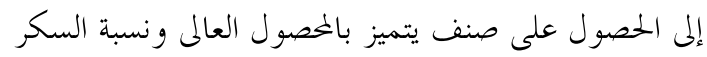

